\title{
Fungicidal, Corrosive, and Mutational Effects of Polyhexamethylene Biguanide Combined with 1-Bromo-3-chloro-5,5-dimethylimidazolidine-2,4-dione
}

\author{
Bing Niu, Wan Huai, Zhirui Deng, and Qin Chen \\ School of Life Science, Shanghai University, Shanghai 200444, China \\ Correspondence should be addressed to Qin Chen; chenqincc@staff.shu.edu.cn
}

Received 6 August 2017; Accepted 1 October 2017; Published 5 November 2017

Academic Editor: Carla Renata Arciola

Copyright (c) 2017 Bing Niu et al. This is an open access article distributed under the Creative Commons Attribution License, which permits unrestricted use, distribution, and reproduction in any medium, provided the original work is properly cited.

\begin{abstract}
Background. The disinfectants polyhexamethylene biguanide (PHMB) and 1-bromo-3-chloro-5,5-dimethylimidazolidine-2,4-dione $(\mathrm{BCDMH})$ each have limitations. So far, their combined usage has not been examined. In this study, the fungicidal activity of combined disinfectant using PHMB and BCDMH, named PB, against Candida albicans was evaluated. Methods. Suspension quantitative fungicidal test and viable fungi count were used to test fungicidal effects against $C$. albicans. Coupon corrosion testing was used to evaluate disinfectants' corrosive effects on stainless steel, copper, and aluminum. The mouse lymphoma assay was used to detect mutations induced by PB. Results and Discussion. Fungicidal activity of the combination of $40 \mathrm{mg} / \mathrm{L}$ PHMB and $40 \mathrm{mg} / \mathrm{L} \mathrm{BCDMH}$ was comparable to, or even better than, those of $600 \mathrm{mg} / \mathrm{L} \mathrm{PHMB}$ or $640 \mathrm{mg} / \mathrm{L} \mathrm{BCDMH}$ alone. The combination of $400 \mathrm{mg} / \mathrm{L}$ PHMB and $400 \mathrm{mg} / \mathrm{L}$ BCDMH exhibited good fungicidal effects in field applications. The combination of $100 \mathrm{mg} / \mathrm{L}$ PHMB and $100 \mathrm{mg} / \mathrm{L}$ BCDMH did not have corrosive effects on stainless steel and no mutagenic effect was observed under the test conditions. Conclusions. The combination of PHMB and BCDMH has strong fungicidal effects and little metal corrosive and mutagenic effect and can be used as one suitable fungicide for wide household and industrial applications, including shipping containers.
\end{abstract}

\section{Background}

PHMB (polyhexamethylene biguanide) is a water-soluble cationic disinfectant with wide clinical, household, and industrial applications [1-3], despite its poor optimal antibacterial effect. BCDMH (1-bromo-3-chloro-5,5-dimethylimidazolidine-2,4-dione), an oxidative disinfectant with efficient bactericidal activity, could cause allergic contact dermatitis and form hypobromous acid ( $\mathrm{HBrO})$, a highly reactive disinfecting ingredient, restricting its continuous effect $[4,5]$. The combination of disinfectants is one strategy to compensate for their individual shortcomings. For example, alcohol with chlorhexidine or alcohol with iodine can enhance bactericidal activity [6]. So far, the combination of PHMB and $\mathrm{BCDMH}$ is not well-characterized. Our previous studies have shown that the bactericidal activity of the combination of PHMB and BCDMH (PB) against Escherichia coli and Staphylococcus aureus was significantly greater than that of either PHMB or BCDMH alone [7]. Therapy for Candida infections is a challenge as one of the most cunning and adaptive organisms that exists [8]. Because PB is necessary to kill fungi as a new disinfectant, it can meet the needs of disinfectants in the application. Besides, the practical application environment is complex, and it is necessary to explore the efficacy of PB to kill fungi. To develop an efficient and comprehensive disinfectant, fungicidal effect needs to be considered. A variety of factors such as concentration, duration, ambient temperature, humidity, wind force, and light intensity could affect disinfectant efficiency in field application [9-11]. Valiente Moro et al. use 16S rRNA PCR to analyze bacteria community [12], and 18S rRNA PCR and Illumina high-throughput sequencing were used to analyze fungi community with PB treated in this paper.

An optimal disinfectant should not only exhibit efficient fungicidal activity but should also be minimally corrosive 
and nontoxic. It is usual for one disinfectant to have some disadvantage, for example, metal corrosion and mutagenicity. Port disinfection includes goods and container disinfection. Containers are typically made of aluminum and stainless steel; general corrosion can be investigated by coupon corrosion testing [13]. Sekine et al. studied the corrosive effects of acids on stainless steel and carbon steels based on weight loss [14-16]. Disinfectant mutagenicity and toxicity were investigated using L5178Y $t k^{+/-}$cells, which have been used to examine regulatory genotoxicity for over three decades and will continue to be a mainstay of internationally recommended testing batteries for the determination of in vitro mammalian cell genotoxicity [17].

Therefore, we tried to use $\mathrm{PHMB}$ and BCDMH for combination and employed the methods mentioned above to attempt to find appropriate concentrations for experiment and practical applications.

\section{Materials and Methods}

2.1. Quantitative Suspension Test. Candida albicans ATCC 10231 derived from American Type Culture Collection was provided by the Shanghai Entry-Exit Inspection and Quarantine Bureau. A single colony was added to Sabouraud Dextrose Broth Medium (SDB) and cultured at $37^{\circ} \mathrm{C}$ for $18-24 \mathrm{~h}$ in shaking incubator. Cell suspensions were centrifuged at 3000 gravitational acceleration (abbreviation, $3000 \mathrm{~g}$ ) for $5 \mathrm{~min}$ and washed twice with tryptone saline solution (TPS). The precipitate was resuspended in TPS to obtain a final concentration of $1 \times 10^{8} \mathrm{cfu} / \mathrm{mL}$ to $5 \times 10^{8} \mathrm{cfu} / \mathrm{mL}$. The bacterial suspension was mixed with $3 \%$ bovine serum albumin $(1: 1)$, and $1 \mathrm{~mL}$ of the resulting cell suspension was mixed with $4 \mathrm{~mL}$ of a solution containing PHMB (Hangzhou LC-Chem Co., Ltd., Hangzhou, China), BCDMH (Taixing Jiansheng Fine Biological Technology Co., Ltd., Taixing, China), or both (i.e., PB) and incubated for $3 \mathrm{~min}$. Then, $0.5 \mathrm{~mL}$ of the above mixture was supplemented with $4.5 \mathrm{~mL}$ of neutralizer $(6 \mathrm{~g} / \mathrm{L}$ sodium thiosulfate, $2.5 \mathrm{~g} / \mathrm{L}$ sodium sulfite, $5 \mathrm{~g} / \mathrm{L}$ Tween 80 , and $7 \mathrm{~g} / \mathrm{L}$ lecithin in TPS) and incubated for $10 \mathrm{~min}$. The neutralized solution was serially diluted $(1: 10)$ with TPS, and $1 \mathrm{~mL}$ of each dilution was mixed with $15 \mathrm{~mL}$ of molten $\left(40-45^{\circ} \mathrm{C}\right)$ Sabouraud Dextrose Agar Medium (SDA) and poured in sterile Petri dishes. The dishes were incubated at $37^{\circ} \mathrm{C}$ until countable colonies appeared. Colonies were then counted.

\subsection{Field Application}

2.2.1. Container Surface Disinfection. Filter paper pads (1 $\times 1 \mathrm{~cm}$ ) for field application were prepared by applying $10 \mu \mathrm{L}$ of bacteria suspension (bacteria, $5 \times 10^{5}$ to $5 \times$ $10^{6} \mathrm{cfu} / \mathrm{mL}$ ) onto one filter paper pad. Four paper pads were pasted on each side of a container (front, back, left, and right), and eight paper pads were pasted on goods package wooden boxes or paper or plastic cover. Then, $10 \mathrm{x}$ PB (1x PB indicates $10 \mathrm{mg} / \mathrm{L} \mathrm{PHMB}+10 \mathrm{mg} / \mathrm{L} \mathrm{BCDMH}$ ) was sprayed on the paper pads one time. The size of droplets, distance, amounts, and duration were $80-120 \mu \mathrm{m}, 5-10 \mathrm{~cm}$, $\sim 100 \mathrm{~mL} / \mathrm{m}^{2}$, and $3 \mathrm{~min}$, respectively. Paper pads were torn down and were eluted with $10 \mathrm{~mL}$ neutralizer. The neutralized solution was serially diluted $(1: 10)$ with TPS and cultured using the plate culture method. The viable bacteria were calculated. For organic material inference test, the procedure was same as above, except that paper pads were prepared with bacteria suspension containing $10 \%$ bovine serum albumin. A diluted solution $(220 \mathrm{mg} / \mathrm{L}$ dioctyldimethylammonium/didecyldimethylammonium, $200 \mathrm{mg} / \mathrm{L}$ naphthamine) from disinfectant U (U-lai Jie Chemical Technology Co., Ltd., Shanghai, China), a widely used port disinfectant, was used for comparison.

2.2.2. Analysis of Fungi Community Structures. Spray the surface with 10x PB solution and wait for $3 \mathrm{~min}$, and then prepare three independent samples from three $5 \mathrm{~cm} \times 5 \mathrm{~cm}$ surfaces by brushing surface with swabs and immersing in neutralizer solution. DNA was extracted from samples using the EZNA ${ }^{\circledR}$ Soil DNA Kit (Omega Bio-tek, Norcross, GA, US) and amplified with primer ITS1F (CTTGGTCATTTAGAG GAAGT AA) and primer 2043R (GCTGCGTTCTTCATCGATGC) with a PCR system (ABI GeneAmp ${ }^{\circledR}$ 9700). The reaction conditions were $95^{\circ} \mathrm{C}$ for $3 \mathrm{~min}, 95^{\circ} \mathrm{C}$ for $30 \mathrm{~s}, 55^{\circ} \mathrm{C}$ for $30 \mathrm{~s}, 72^{\circ} \mathrm{C}$ for $45 \mathrm{~s}$, and $72^{\circ} \mathrm{C}$ for $10 \mathrm{~min}$, for $28-36$ cycles. PCR operations were performed in triplicate using $20 \mu \mathrm{L}$ mixtures containing $4 \mu \mathrm{L}$ of $5 \mathrm{x}$ FastPfu Buffer, $2 \mu \mathrm{L}$ of $2.5 \mathrm{mM}$ dNTPs, $0.8 \mu \mathrm{L}$ of each primer $(5 \mu \mathrm{M}), 0.4 \mu \mathrm{L}$ of FastPfu Polymerase, and $10 \mathrm{ng}$ of template DNA. Illumina highthroughput sequencing was performed by Shanghai Majorbio Bio-Pharm Technology Co., Ltd. (Shanghai, China).

2.3. Coupon Corrosion Test. Stainless steel (the details could be referred to in support information S1 in Supplementary Material available online at https://doi.org/10.1155/2017/ 4357031), copper, and aluminum coupons were purchased from East China Pharmaceutical Co., Ltd., Huangyan, China. After treatment with anhydrous ethanol, cleaned metal coupons were dried in a $50^{\circ} \mathrm{C}$ incubator for $1 \mathrm{~h}$ and weighed three times when temperature dropped to room temperature. The metal coupons were hooked in $600 \mathrm{~mL}$ of disinfectant with concentrations of $1 \mathrm{x} \mathrm{PB}$ and $10 \mathrm{x} \mathrm{PB}$ and kept free of light for $72 \mathrm{~h}$. Metal coupons hooked in water were used as controls. Then coupons were removed from solutions and washed with water. Metal coupons were placed in plates with filter paper and dried for $1 \mathrm{~h}$ in a $50^{\circ} \mathrm{C}$ incubator. Changes in metal coupon color and weight were recorded. The metal corrosion rate $R(\mathrm{~mm} / \mathrm{a})$ was calculated as follows:

$$
R=\frac{8.76 \times 10^{7} \times\left(m-m_{t}\right)}{S \times t \times d}
$$

where $m$ is the weight of the metal before treatment $(\mathrm{g}), m_{t}$ is the weight of the metal after treatment $(\mathrm{g}), S$ is the total surface area of the metal coupon $\left(\mathrm{cm}^{2}\right), t$ is the treatment time (h), and $d$ is the density of the metal coupon $\left(\mathrm{kg} / \mathrm{m}^{3}\right)$. $S$ for one coupon in the test was $9.8017 \mathrm{~cm}^{2}$. The densities of stainless steel, copper, and aluminum were $7.93 \mathrm{~g} / \mathrm{cm}^{3}, 8.9 \mathrm{~g} / \mathrm{cm}^{3}$, and $2.73 \mathrm{~g} / \mathrm{cm}^{3}$, respectively. 
TABLE 1: Fungicidal activity of PB.

\begin{tabular}{lccccrc}
\hline & PB (mg/L) & LR & $\begin{array}{c}\text { PHMB } \\
(\mathrm{mg} / \mathrm{L})\end{array}$ & LR & $\begin{array}{c}\text { BCDMH } \\
(\mathrm{mg} / \mathrm{L})\end{array}$ \\
BCDMH & PHMB & & 300 & $1.81 \pm 0.02$ & 80 & $0.08 \pm 0.03$ \\
10 & 10 & $0.37 \pm 0.31$ & 400 & $2.03 \pm 0.02$ & 160 & $0.40 \pm 0.05$ \\
20 & 20 & $2.16 \pm 0.18$ & 500 & $2.79 \pm 0.05$ & 320 & $2.82 \pm 0.02$ \\
40 & 40 & $5.18 \pm 0.79$ & $6.31 \pm 0.31$ & 640 \\
60 & 60 & $5.70 \pm 0.08$ & 600 & $4.32 \pm 0.27$ \\
\hline
\end{tabular}

Notes. $n=3$. All data are expressed as means \pm standard deviation.

TABLE 2: LR of PB on C. albicans in field application.

\begin{tabular}{|c|c|c|c|c|c|c|c|c|}
\hline \multirow{2}{*}{ Sides } & \multicolumn{3}{|c|}{ Logarithmic values of viable cells (+0\% serum) } & \multirow{2}{*}{$\mathrm{LR}_{1}$} & \multicolumn{3}{|c|}{ Logarithmic values of viable cells $(+10 \%$ serum $)$} & \multirow{2}{*}{$\mathrm{LR}_{2}$} \\
\hline & $\mathrm{H}_{2} \mathrm{O}$ & 10x PB & $\mathrm{U}$ & & $\mathrm{H}_{2} \mathrm{O}$ & 10x PB & $\mathrm{U}$ & \\
\hline Front & $4.69 \pm 0.06$ & $3.75 \pm 0.02$ & $4.02 \pm 0.05$ & 0.94 & $4.26 \pm 0.04$ & $3.43 \pm 0.04$ & $3.50 \pm 0.08$ & 0.83 \\
\hline Behind & $4.85 \pm 0.08$ & $3.16 \pm 0.09$ & $3.61 \pm 0.10$ & 1.69 & $4.09 \pm 0.16$ & $3.53 \pm 0.25$ & $3.96 \pm 0.08$ & 0.56 \\
\hline Left & $4.77 \pm 0.16$ & $3.75 \pm 0.05$ & $4.07 \pm 0.07$ & 1.02 & $4.16 \pm 0.04$ & $3.76 \pm 0.07$ & $4.20 \pm 0.07$ & 0.4 \\
\hline Right & $4.82 \pm 0.03$ & $3.63 \pm 0.07$ & $4.34 \pm 0.11$ & 1.19 & $4.17 \pm 0.20$ & $3.79 \pm 0.04$ & $3.89 \pm 0.04$ & 0.38 \\
\hline Goods & $4.36 \pm 0.11$ & $3.16 \pm 0.14$ & $4.26 \pm 0.11$ & 1.2 & $4.13 \pm 0.04$ & $3.32 \pm 0.22$ & $3.90 \pm 0.11$ & 0.81 \\
\hline
\end{tabular}

Notes. All data are expressed as means \pm standard deviation. PB (1x) indicates $10 \mathrm{mg} / \mathrm{L}$ PHMB and $10 \mathrm{mg} / \mathrm{L}$ BCDMH. LR1 and LR2 represent the mean logarithmic reduction in fungi with $0 \%$ bovine serum and $10 \%$ bovine serum after 10x PB treatment, respectively.

2.4. Mouse Lymphoma Assay. The mouse lymphoma assay was performed using L5178Y $t k^{+/-}$cloned cells, clone 3.7.2C (provided by the Cell Bank of Chinese Academy of Sciences) [18]. Cells were cultured as described by Fellows et al. [17]. Prior to testing, to remove spontaneous mutant cells, cells were treated for $24 \mathrm{~h}$ with THMG (RPMI (Invitrogen, Paisley, $\mathrm{UK}$ ) containing $3 \mathrm{mg} / \mathrm{L}$ thymidine, $5 \mathrm{mg} / \mathrm{L}$ hypoxanthine, $0.1 \mathrm{mg} / \mathrm{L}$ methotrexate, and $7.5 \mathrm{mg} / \mathrm{L}$ glycine) medium and then transferred to THG medium (not containing methotrexate) for $48 \mathrm{~h}$. The THG medium was changed to RPMI 1640 medium, and cells were incubated for $72 \mathrm{~h}$ in a flask [18]. The PB concentrations were selected based on the criteria set in the Organisation for Economic Cooperation and Development (OECD) guidelines, in which mutagenicity should be tested at concentrations causing high cytotoxicity (10-20\% relative total growth for the maximum concentration). Mutant frequency determination was performed as described in OECD guideline for $t k$ locus mutation assay [19]. Exogenous metabolizing systems with 2\% S9 fraction were used in the test.

To determine cloning efficiency, cultures were plated into two 96-well plates at $\sim 1.6$ cells/well in RPMI 1640 medium containing $20 \%$ heat inactivated donor horse serum (DHS). To determine TFT resistance, cultures were plated into two 90-well plates at 2000 cells/well in RPMI 1640 medium containing $20 \%$ DHS and $3 \mu \mathrm{g} / \mathrm{mL}$ TFT [17]. Plates were incubated for 12 days. Viability and mutant frequency were analyzed by calculating related indices, such as relative suspension growth (RSG), plate efficiency $\left(\mathrm{PE}_{0}, \mathrm{PE}_{2}\right)$, relative survival rate $(\mathrm{RS})$, and mutant frequency $(\mathrm{MF})$ using standard methods [20].

\section{Results}

3.1. Effect of $P B$ on $C$. albicans. Quantitative fungicidal tests were used to assess the effects of $\mathrm{PB}$ on $C$. albicans in a 3 min duration. As shown in Table 1, the fungicidal activity of the combined and individual disinfectants increased as the concentration increased. $\mathrm{PB}(4 \mathrm{x})$ brought about log reduction $(\mathrm{LR})=5.18$, larger than that by $600 \mathrm{mg} / \mathrm{L}$ PHMB $(\mathrm{LR}=4.31)$ or that by $640 \mathrm{mg} / \mathrm{L} \mathrm{BCDMH}(\mathrm{LR}=4.32)$.

3.2. Effect of $P B$ on $C$. albicans and Fungal Communities in the Field. $\mathrm{PB}(10 \mathrm{x})$ was sprayed onto filter paper pads pasted on different sides of a container. Table 2 shows that the logarithmic values of viable cells treated with 10x PB were lower than those of cells treated with the port disinfectant $\mathrm{U}$, indicating $\mathrm{PB}$ is better than disinfectant U. Serum in $C$. albicans cell suspension, as one organic material, lowered LR fungicidal effect. Therefore, the presence of serum weakened the fungicidal activity of PB to a certain extent.

Fungal communities on container surfaces before and after 10x PB treatment are summarized in Figure 1. The average proportion of Candida in the $\mathrm{PB}$ group was $5.36 \%$ and the average proportion in the CK group was $7.40 \%$, suggesting significant differences in fungal communities before and after treatment. Community barplot analysis showed that there were 136 total fungi in the CK group and 64 fungi in the $\mathrm{PB}$ group on genus level, indicating that $10 \mathrm{x} \mathrm{PB}$ has good fungicidal effect.

3.3. PB Corrosive Effect on Metal. Stainless steel, copper, and aluminum coupons were soaked in $1 \mathrm{x} \mathrm{PB}$ and $10 \mathrm{x}$ PB for $72 \mathrm{~h}$. The surface changes are presented in Figure 2. The 

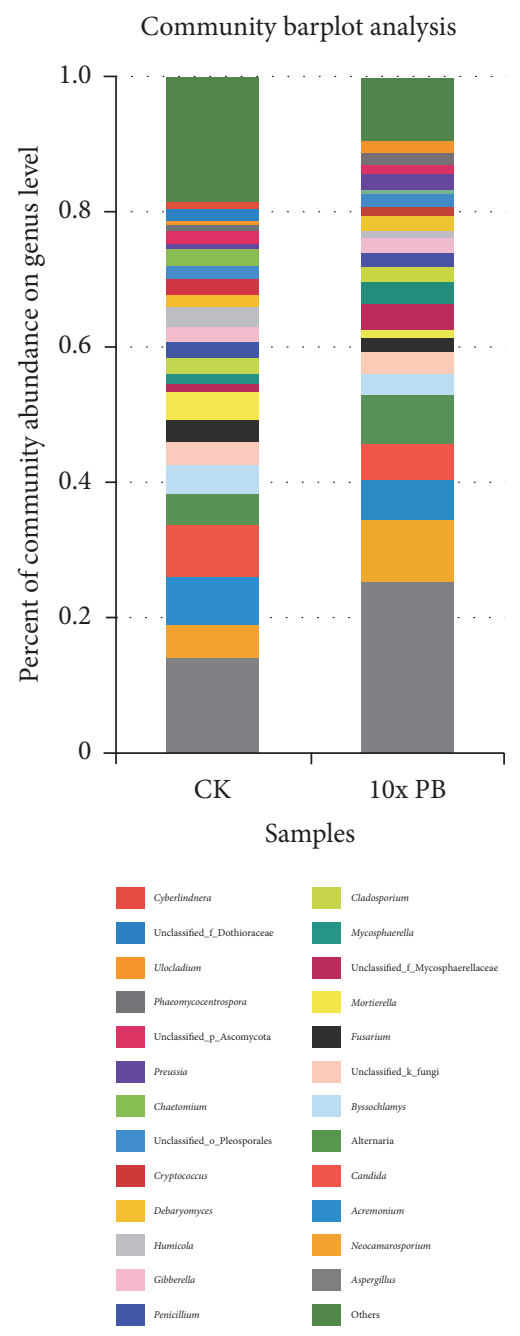

FIGURE 1: Effect of PB on community abundance on genus level.

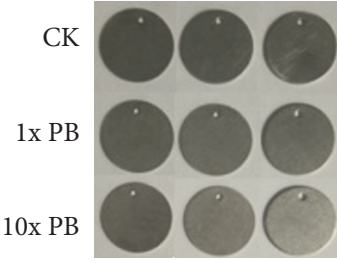

Stainless steel

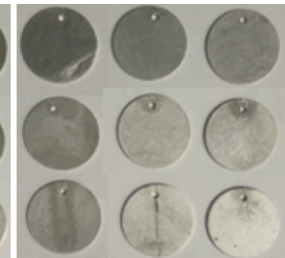

Aluminum

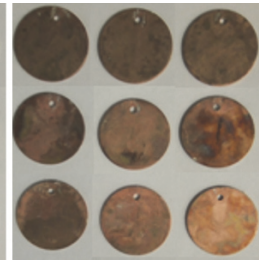

Copper

FIGURE 2: Surface change of metal coupons.

faces of stainless steel and aluminum coupons did not exhibit significant changes, and copper coupon face color became lighter, and the more concentrated the PB solutions were, the lighter they became.

The corrosion rates $(R)$ of various metals are shown in Table 3. The metal coupons treated with $1 \mathrm{x} P B$ and $10 \mathrm{x}$ PB did not exhibit severe corrosion. PB (1x or 10x) had almost no corrosive effect on stainless steel coupons and $\mathrm{PB}$ (10x) had mild and moderate corrosive effects on aluminum
TABLE 3: Metal coupons corrosion of PB.

\begin{tabular}{lcc}
\hline Metal coupons & $R(\mathrm{~mm} / \mathrm{a}, 1 \mathrm{x} \mathrm{PB})$ & $R(\mathrm{~mm} / \mathrm{a}, 10 \mathrm{x} \mathrm{PB})$ \\
\hline Stainless steel & $0.003 \pm 0.0023$ & $0.002 \pm 0.0050$ \\
Aluminum & $0.003 \pm 0.0026$ & $0.032 \pm 0.0104$ \\
Copper & $0.038 \pm 0.0415$ & $0.109 \pm 0.0298$ \\
\hline
\end{tabular}

Notes. All data are expressed as means \pm standard deviation. $R<0.01$, almost no corrosion; $0.01 \leq R<0.100$, mild corrosion; $0.100 \leq R<1.00$, moderate corrosion; $R \geq 1.00$, severe corrosion. 
TABLE 4: Effects of PB on mutant frequency of L5178Y cells.

\begin{tabular}{lccccccccccc}
\hline Groups & $\begin{array}{c}\text { RSG } \\
(\%)\end{array}$ & $\begin{array}{c}\mathrm{PE}_{0} \\
(\%)\end{array}$ & $\begin{array}{c}\mathrm{SE} 9 \\
(\%)\end{array}$ & $\begin{array}{c}\mathrm{RS} \\
(\%)\end{array}$ & $\begin{array}{c}\mathrm{MF} \\
\left(10^{-6}\right)\end{array}$ & Groups & $\begin{array}{c}\mathrm{RSG} \\
(\%)\end{array}$ & $\begin{array}{c}\mathrm{PE}_{0} \\
(\%)\end{array}$ & $\begin{array}{c}\mathrm{PE}_{2} \\
(\%)\end{array}$ & $\begin{array}{c}\mathrm{RS} \\
(\%)\end{array}$ & $\begin{array}{c}\mathrm{MF} \\
\left(10^{-6}\right)\end{array}$ \\
\hline 1 & 74.1 & 61.3 & 66.74 & 73.49 & 141.4 & 1 & 78.2 & 53.94 & 56.3 & 78.11 & 159.2 \\
2 & 60.2 & 51.67 & 63.96 & 70.43 & 140.1 & 2 & 72.2 & 43.32 & 47.36 & 65.7 & 95.2 \\
3 & 46.3 & 34.25 & 32.58 & 35.88 & 86.4 & 3 & 59.5 & 37.72 & 45.31 & 62.86 & 62.1 \\
4 & 29.9 & 27.83 & 26.33 & 28.99 & 122.8 & 4 & 17.7 & 23.42 & 27.83 & 38.61 & 71.6 \\
$\mathrm{H}_{2} \mathrm{O}$ & 100 & 75.76 & 90.82 & 100 & 138.9 & $\mathrm{H}_{2} \mathrm{O}$ & 100 & 64.43 & 72.08 & 100 & 171.5 \\
$\mathrm{CP}$ & 30.1 & 38.93 & 37.95 & 41.79 & 380.9 & $\mathrm{MMS}$ & 34.0 & 26.03 & 31.81 & 44.13 & 454.4 \\
\hline
\end{tabular}

Notes. Groups 1-4: $0.8 \mu \mathrm{g} / \mathrm{mL}$ PHMB + 0.8 $\mu \mathrm{g} / \mathrm{mL}$ BCDMH, $1.6 \mu \mathrm{g} / \mathrm{mL}$ PHMB $+1.6 \mu \mathrm{g} / \mathrm{mL}$ BCDMH, $3.2 \mu \mathrm{g} / \mathrm{mL}$ PHMB $+3.2 \mu \mathrm{g} / \mathrm{mL}$ BCDMH, and $6.4 \mu \mathrm{g} / \mathrm{mL}$ PHMB $+6.4 \mu \mathrm{g} / \mathrm{mL}$ BCDMH, respectively (final concentration). CP: $3 \mu \mathrm{g} / \mathrm{mL}$ cyclophosphamide, MMS: $3 \mu \mathrm{g} / \mathrm{mL}$ cyclophosphamide, and $10 \mu \mathrm{g} / \mathrm{mL}$ methyl methanesulfonate. $n=3$.

and copper coupons, respectively; corrosion increased as PB concentration increased.

3.4. Mouse Lymphoma Assay. Mouse lymphoma L5178Y cells lacking spontaneous mutations were exposed to appropriate concentrations of $\mathrm{PB}(0.8 \sim 6.4 \mu \mathrm{g} / \mathrm{mL} \mathrm{PHMB}+0.8 \sim$ $6.4 \mu \mathrm{g} / \mathrm{mL} \mathrm{BCDMH}$ ) based on prescreening. RSG and other indicators were calculated according to cell or cell colony counts (Table 4). RSG, $\mathrm{PE}_{0}, \mathrm{PE}_{2}$, and RS decreased as the $\mathrm{PB}$ concentration increased, showing that $\mathrm{PB}$ has a certain level of toxicity on cells. MF of cells treated with various PB solutions did not differ significantly from that of cells treated with $\mathrm{H}_{2} \mathrm{O}$, and no dose effect was observed, indicating that $\mathrm{PB}$ had no mutagenic effects under the test conditions.

\section{Discussion}

$\mathrm{PB}$ is a combined disinfectant established in our laboratory, and it is formed with PHMB and BCDMH. We have studied the $\mathrm{PB}$ bactericidal effects on E. coli, Pseudomonas aeruginosa (unpublished data), and S. aureus [7]. The related results showed that $\mathrm{PB}$ has relatively optimal bactericidal activity at relatively low concentration [7]. In this study, we try to examine its fungicidal, metal corrosive, and mutational effects. The results showed that, as expected, PB exhibited significant fungicidal effect against $C$. albicans and could produce high fungicidal activity only with $\mathrm{PB}$ weight which was $1 / 15$ of $\mathrm{PHMB}$ weight or $1 / 16$ of $\mathrm{BCDMH}$ weight when they were used alone, indicating combination of $\mathrm{PHMB}$ and $\mathrm{BCDMH}$ could promote bactericidal activity and could be used as one broad-spectrum antimicrobial agent.

Containers, as main transportation apparatus, undergo a range of environmental and biological contaminants during transport. They must be disinfected carefully to remove infectious disease microbial organisms before loading [21-23]. Microbial communities can be affected by various natural factors, such as wind, moisture, or some environmental factors, such as agrochemical or antimicrobial agent residues. Our results showed that $\mathrm{PB}$ has strong effect on microbial community abundance, could obviously inhibit or extinct some microbial community, and change community composition; especially for fungi in the experiment, fungal community abundance was changed a lot. Although PB fungicidal effect was much better than that of port disinfectant $U$, it could not extinct all fungal communities. It is probably because some fungus was at spore phase. It is possible to disinfect all fungal communities by elevating $\mathrm{PB}$ concentration, or it is impossible to sterilize all fungal communities only with $\mathrm{PB}$. It can be reached by combining $\mathrm{PB}$ with other disinfectants or physical factors such as UV, microwave, and plasma.

Corrosive effects of chemical disinfectants limit their application scope. Except for good disinfection effect, an optimal disinfectant should have no or little corrosive effect on containers, especially on metals that containers are made of. The results about metal corrosion indicated that $\mathrm{PB}$ has no corrosive effect on stainless steel and little corrosive effect on aluminum and copper, suggesting it can be used relatively safely in metal containers. If diluted PB solution (e.g., $5 \mathrm{x}$ ) is used, it will be safer for metal containers.

For field application, disinfectants may be sprayed onto surfaces of goods and/or containers. It is requested for disinfectants to be nontoxic and have no mutagenic effect on human and livestock cells. Harmand used L5178Y cells to detect mutant of cells treated with PHMB $(0 \sim 100 \mu \mathrm{g} / \mathrm{mL})$ and found that both $50 \mu \mathrm{g} / \mathrm{mL}$ and $100 \mu \mathrm{g} / \mathrm{mL}$ PHMB had high toxicity to cells but had no mutant effects [24]. The question whether PHMB is still nontoxic and has no mutagenic effect when it is combined with BCDMH must be answered. Our results proved that addition of $\mathrm{BCDMH}$ did not produce additional mutagenicity.

In summary, $\mathrm{PB}$ has high fungicidal activity against $C$. albicans and is safe in field application and can be used as one substitute for typical port disinfectant.

\section{Conflicts of Interest}

There are no conflicts of interest related to this paper.

\section{Authors' Contributions}

Bing Niu and Wan Huai contributed equally to the work.

\section{Acknowledgments}

This study was supported by the National Key Technology Support Program of China (no. 2013BAD12B06) and the 
National Key Research and Development Program of China (no. 2016YFD0501101).

\section{References}

[1] G. Müller, T. Koburger, and A. Kramer, "Interaction of polyhexamethylene biguanide hydrochloride (PHMB) with phosphatidylcholine containing $\mathrm{o} / \mathrm{w}$ emulsion and consequences for microbicidal efficacy and cytotoxicity," Chemico-Biological Interactions, vol. 201, no. 1-3, pp. 58-64, 2013.

[2] K. Chindera, M. Mahato, A. Kumar Sharma et al., "The antimicrobial polymer PHMB enters cells and selectively condenses bacterial chromosomes," Scientific Reports, vol. 6, Article ID 23121, 2016.

[3] S. Ampawong and P. Aramwit, "A study of long-term stability and antimicrobial activity of chlorhexidine, polyhexamethylene biguanide, and silver nanoparticle incorporated in sericinbased wound dressing," Journal of Biomaterials Science, Polymer Edition, vol. 28, no. 13, pp. 1286-1302, 2017.

[4] G. Dalmau, M. Estela Martínez-Escala, and V. Gázquez, "Swimming pool contact dermatitis caused by 1-bromo-3-chloro-5,5dimethyl hydantoin," Journal of Contact Dermatitis, vol. 66, no. 6, Article ID 3350339, pp. 335-339, 2012.

[5] L. Yang, C. Schmalz, J. Zhou et al., "An insight of disinfection by-product (DBP) formation by alternative disinfectants for swimming pool disinfection under tropical conditions," Water Research, vol. 101, pp. 535-546, 2016.

[6] W. A. Rutala and D. J. Weber, "Disinfection, sterilization, and antisepsis: An overview," American Journal of Infection Control, vol. 44, no. 5, pp. el-e6, 2016.

[7] W. Huai, Z. Deng, and Q. Chen, "Bactericidal Activity and Physiological Effects of Combined Application of PolyHexamethylene Biguanide Hydrochloride and 1-bromo-3chloro-5, 5-dimethylimidazolidine-2, 4-dione on Staphylococcus aureus," in Proceedings of the International Conference on Biological Engineering and Pharmacy 2016 (BEP 2016), Shanghai, China, December 2016.

[8] E. H. Endo, D. A. Garcia Cortez, T. Ueda-Nakamura, C. V. Nakamura, and B. P. Dias Filho, "Potent antifungal activity of extracts and pure compound isolated from pomegranate peels and synergism with fluconazole against Candida albicans," Research in Microbiology, vol. 161, no. 7, pp. 534-540, 2010.

[9] K. Wang, V. Tian, N. Gu, C. Zhang, and J. Niu, "Study on synergistic effect of bactericidal effect of chlorine dioxide solution by surfactant," Journal of Hygiene Research, vol. 42, no. 2, pp. 282-285, 2013.

[10] P. M. Schneider, "New technologies and trends in sterilization and disinfection," American Journal of Infection Control, vol. 41, no. 5, pp. S81-S86, 2013.

[11] W. A. Rutala and D. J. Weber, "Disinfection and sterilization: An overview," American Journal of Infection Control, vol. 41, no. 5, pp. S2-S5, 2013.

[12] C. Valiente Moro, J. Thioulouse, C. Chauve, P. Normand, and L. Zenner, "Bacterial taxa associated with the hematophagous mite Dermanyssus gallinae detected by 16 S rRNA PCR amplification and TTGE fingerprinting," Research in Microbiology, vol. 160, no. 1, pp. 63-70, 2009.

[13] "Astm I. 1990. ASTM G31-72: Standard Practice for Laboratory Immersion Corrosion Testing of Metals".

[14] I. Sekine, S. Hatakeyama, and Y. Nakazawa, "Effect of water content on the corrosion behaviour of type 430 stainless steel in formic and acetic acids," Electrochimica Acta, vol. 32, no. 6, pp. 915-920, 1987.

[15] S. K. Singh and A. K. Mukherjee, "Kinetics of mild steel corrosion in aqueous acetic acid solutions," Journal of Materials Science and Technology, vol. 26, no. 3, pp. 264-269, 2010.

[16] S. K. Singh, A. K. Mukherjee, and M. M. Singh, "Kinetics of mild steel corrosion in aqueous formic acid solutions," Canadian Metallurgical Quarterly, vol. 50, no. 2, pp. 186-194, 2011.

[17] M. D. Fellows, A. Mcdermott, K. R. Clare, A. Doherty, and M. J. Aardema, "The spectral karyotype of L5178Y TK+/- mouse lymphoma cells clone 3.7.2C and factors affecting mutant frequency at the thymidine kinase (tk) locus in the microtitre mouse lymphoma assay," Environmental and Molecular Mutagenesis, vol. 55, no. 1, pp. 35-42, 2014.

[18] M. I. Vasquez, M. Tarapoulouzi, N. Lambrianides et al., "Assessing the potential of pharmaceuticals and their transformation products to cause mutagenic effects: Implications for gene expression profiling," Environmental Toxicology and Chemistry, vol. 35, no. 11, pp. 2753-2764, 2016.

[19] Chemistry, "Test No. 476: In vitro Mammalian Cell Gene Mutation Test," Oecd Guidelines for the Testing of Chemicals, vol. 1, no. 10, 2010.

[20] M. Lloyd and D. Kidd, The Mouse Lymphoma Assay, Springer, NY, USA, 2012.

[21] S. Nijhawan, N. K. Jain, M. P. Sharma et al., "An economical endoscope disinfection container.," Indian Journal of Gastroenterology, vol. 20, no. 6, pp. 249-250, 2001.

[22] P. Reiter, "The standardised freight container: Vector of vectors and vector-borne diseases," Revue Scientifique et Technique de l'OIE, vol. 29, no. 1, pp. 57-64, 2010.

[23] V. M. Walden, E.-A. Lamond, and S. A. Field, "Container contamination as a possible source of a diarrhoea outbreak in Abou Shouk camp, Darfur province, Sudan," Disasters, vol. 29, no. 3, pp. 213-221, 2005.

[24] U. Bernauer, "Opinion of the scientific committee on consumer safety (SCCS) - 2nd Revision of the safety of the use of poly(hexamethylene) biguanide hydrochloride or polyaminopropyl biguanide (PHMB) in cosmetic products," Regulatory Toxicology and Pharmacology, vol. 73, no. 3, pp. 885-886, 2015. 

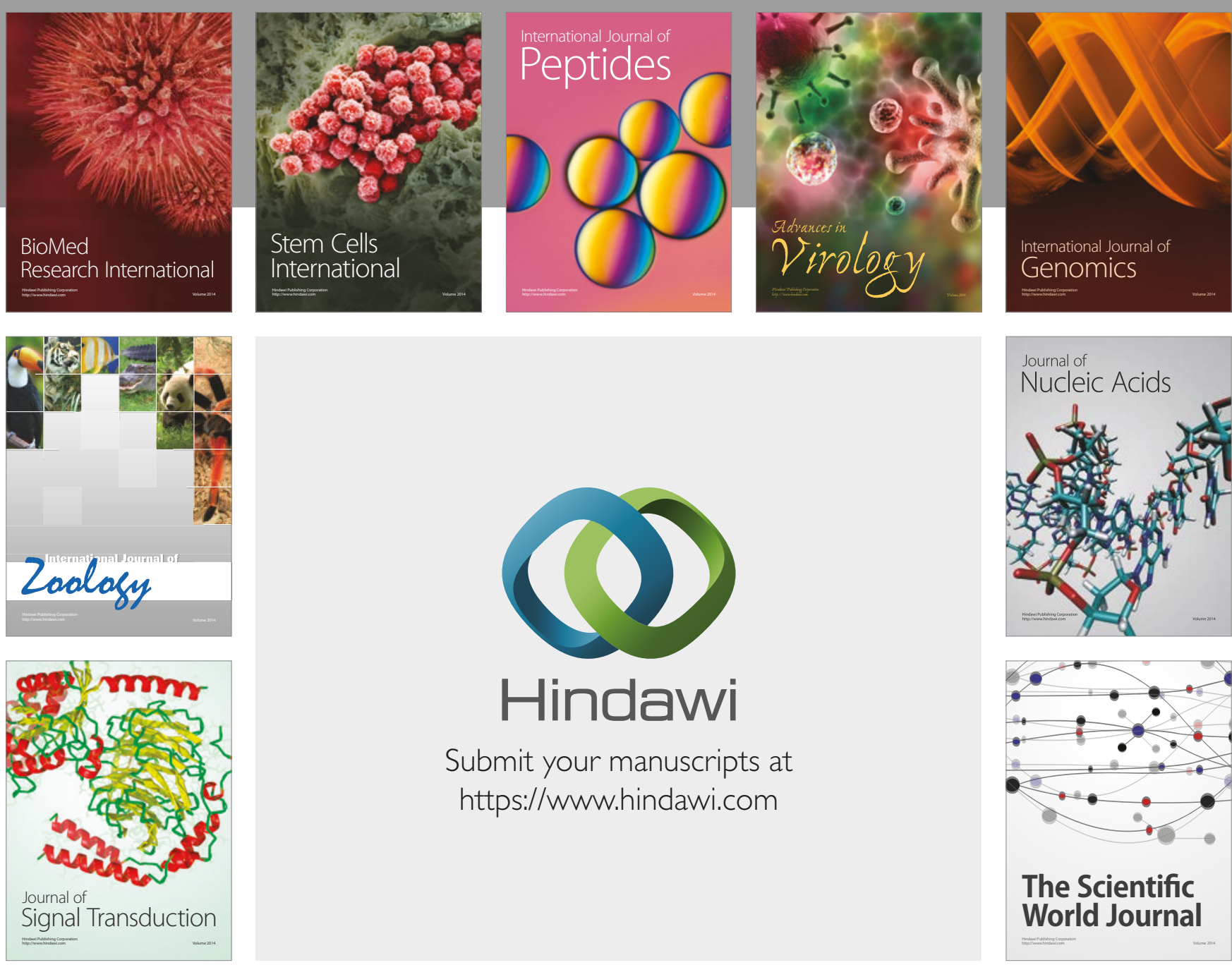

Submit your manuscripts at

https://www.hindawi.com
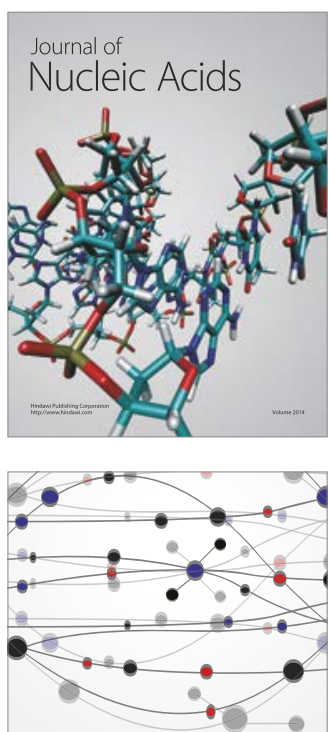

The Scientific World Journal

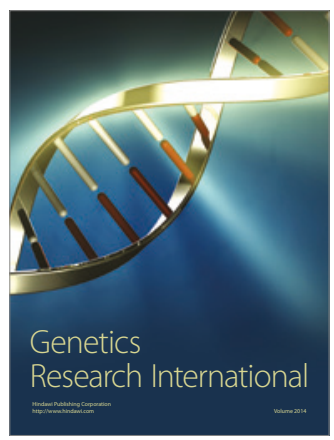

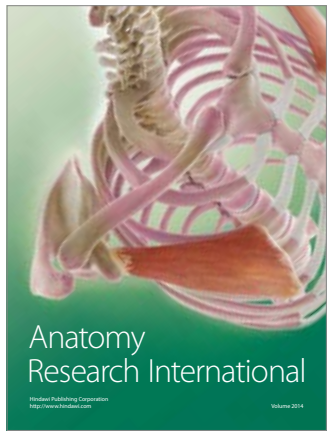

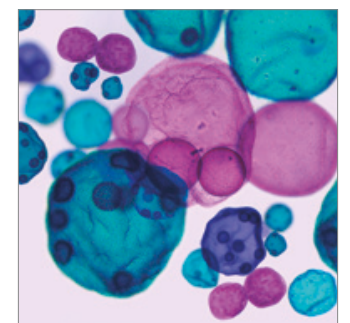

International Journal of Microbiology
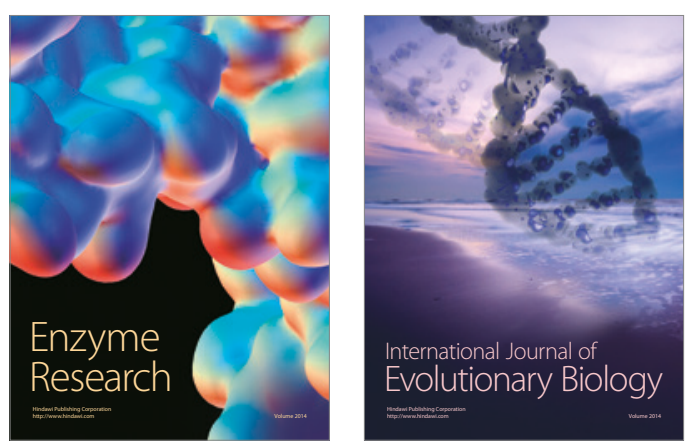
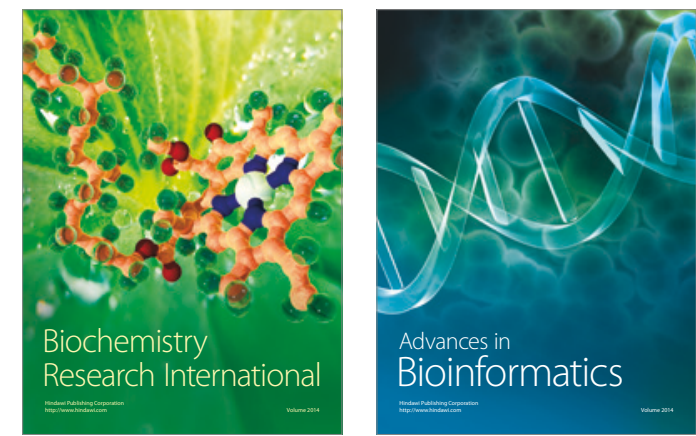

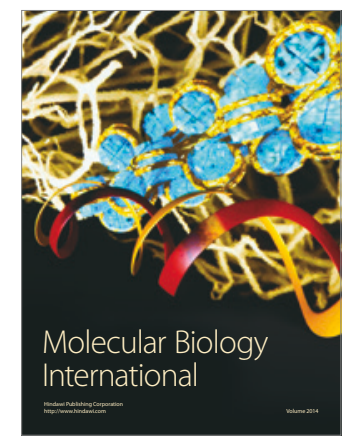

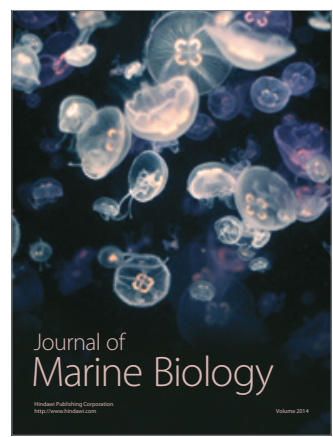

